\section{The Iron-Protein Link in Hæmoglobin and Myoglobin}

IT is generally considered that the hæm iron in hæmoglobin and myoglobin and their derivatives is bound to the apoprotein through histidine imidazole groups, although there is some uncertainty ${ }^{1}$ whether the stronger of the two postulated imidazoles (ascribed $p K_{1}=5 \cdot 3$ in ferrihæmoglobin and ferrimyoglobin ${ }^{2}$ ) has been so identified.

The $p H$ stability eurves of native and recombined horse ferrimyoglobin are shown in Fig. 1, obtained after addition of solutions of the native protein and of the components of the recombined protein to a series of phthalate and phosphate buffers $(p \mathrm{H} 2 \cdot 3-7 \cdot 0$, $\mu=0.05, T=21^{\circ} \mathrm{C}$.). The solutions were stood for $16 \mathrm{hr}$. at $1^{\circ}$ and then $2 \mathrm{hr}$. at $21^{\circ}$ before reading the absorbances at $408.5 \mathrm{~m} \mu$, the Soret $p \mathrm{H} 7.0$ peak. Curves of similar type and approximate position were obtained for ferrihæmoglobin, measured at $405 \mathrm{~m} \mu$. When hæmatin or ætiohæmatin combines with native globin or apomyoglobin at $p H$ 6-7, a comparable major increase in Soret peak absorbance occurs ${ }^{3}$ between $p \mathrm{H} 4$ and 6 (Fig. 1). The curves therefore appear to indicate dissociation of the hæmatin iron from specific groups in the apoprotein.

A reversible equilibrium between 'acid hæmatin' and ferrihæmoglobin exists ${ }^{4}$ within the $p H$ range $3 \cdot 0$ $6 \cdot 0$, and while the curves of Fig. 1 and similar ones obtained by removal of hæmatin with acetone ${ }^{5}$ do not exactly fit dissociation curves of acids with single equilibrium constants, they could represent such curves partly masked by overlapping contributions from other linkages, such as hæmatin propionyl apoprotein or iron - anion ligand.

Since at $p H \mathbf{H} 5 \cdot 3$ only a very small decrease in Soret peak absorbance occurs and only a very small fraction

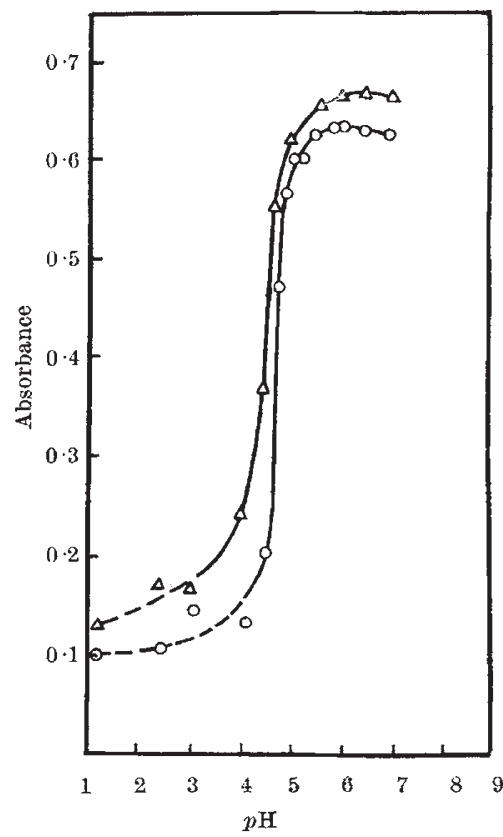

Fig. 1. $p$ H stability curves of native and recombined horse ferrimyoglobin in the $p \mathrm{H}$ range 1-7 from the absorbances at $408.5 \mathrm{~m} \mu$ Native ferrimyoglobin $\left(-\mathrm{O}-\mathrm{O}-\mathrm{O}, 0 \cdot 1 \mathrm{ml}, 9.3 \times 10^{-5} \mathrm{M}\right.$ solution $+10 \mathrm{ml}$. buffer; recombined ferrimyoglobin $(-\Delta-\Delta-)$ $0.05 \mathrm{ml} .1 .8 \times 10^{-4} M$ protohæmatin in $0.01 M$ sodium hydroxide $+0 \cdot 10 \mathrm{ml} .2 \cdot 1 \times 10^{-4} M$ apomyoglobia solution $+10 \mathrm{ml}$. buffer Buffers: $p$ H $1 \cdot 2$, hydrochloric acid; $2 \cdot 3-6 \cdot 2$, phthalate $21^{\circ} \mathrm{C}=0.05$. Temperature of the hæmatin is extracted by acetone $e^{5}$, the specific groups indicated, which I consider to be those binding the hæmatin iron to the apoprotein, are unlikely to be the postulated imidazoles of $p K_{1}=5 \cdot 3$. A $p K$ of this value could be related to dissociation of hæmatin propionyl. Rather it would appear that groups of the nature of aspartyl $\beta$ - or glutamyl $\gamma$-carboxyls $(p K \approx 4 \cdot 7)$ are ionizing. Potentiometric titration studies of horse carboxyhæmoglobin ${ }^{8}$ have also suggested carboxyl groups (of $p K$ approximately this value) linked to the hæm, while ironcarboxyl linkages have been considered to occur in recombined hæmoglobin ${ }^{1}$ and, on evidence from both spectrophotometric and enzymatic activity studies, in the related hæmoprotein, horse-radish peroxidase?

J. E. O'HAGAN

Red Cross Blood Transfusion Service,

Brisbane,

Queensland.

Dec. 12.

${ }^{1}$ Wyman, J., "Adv. Protein Chem.", 4, 407 (1948).

Theorell, H., and Ehrenberg, A., Acta Chem. Scand., 5, 823 (1951).

${ }^{3}$ O'Hagan, J. E., Ph.D. thesis, University of Queensland (1958).

"Holden, H. F., A ust. J. Exp. Biol. and Med. Sci., 14, 291 (1936) Steinhardt, J., and Zaiser, E. M., "Adv. Protein Chem.", 10, $151(1955)$.

${ }^{5}$ Lewis, U. J., J. Biol. Chem., 206, 109 (1954).

${ }^{6} \mathrm{Cohn}$, E. J., Green, A. A., and Blanehard, M. H., J. Amer. Chem. Soc., 59,509 (1937).

Theorell, H., and Paul, K. G., Ark. Kemi, Mineral. Geol., 18, A, No. 12 (1943).

\section{Chromatographic Behaviour of Human Albumin labelled with lodine-|3|}

THE in vivo behaviour of plasma proteins labelled with iodine-131 prepared by methods developed in this laboratory $y^{1,2}$ is almost identical with that of the corresponding proteins labelled with carbon-14 by the biosynthetic procedure ${ }^{3,4}$. Human albumin preparations iodinated by these methods have a chromatographic distribution similar to that of unlabelled albumin when analysed on anion exchange columns of diethylaminoethyl cellulose (Fig. 1). Similar results have been obtained on cation exchange columns of carboxymethyl cellulose. On the other hand, commercially iodinated human albumin (Abbotts, Chicago), which has been extensively used in clinical studies of albumin turnover, has recently been shown to have a chromatographic distribution markedly different from native albumin ${ }^{5}$. It is now recognized that preparations of protein labelled with iodine-131 may be adversely affected by a variety of factors, including the method of fractionation, the technique of iodination ${ }^{1}$, preliminary heat treatment of the protein ${ }^{6}$ and self-irradiation ${ }^{7}$. Investigation of these variables has shown that by far the greatest changes in chromatographic behaviour of albumin labelled with iodine-131 result from self-irradiation.

Human albumin prepared by ion exchange chromatography ${ }^{8}$ was iodinated at a mean ratio of less than 1 atom per molecule using the iodine monochloride method recently described by McFarlane ${ }^{2}$. The effect of self-irradiation was investigated in solutions containing $2-3 \mathrm{mgm}$. albumin and 500-700 $\mu \mathrm{c}$. of iodine-131 per $\mathrm{ml}$. Solutions were stored at $3^{\circ} \mathrm{C}$. and tracer amounts added to human serum at intervals after labelling. Irradiation-levels between 40 and $85 \mathrm{k} . r a d s$ produced a progressive displacement of the radioactive from the native albumin (Fig. 2). The electrophoretic mobility on paper of these irradi- 